\title{
THE FUNCTION OF INDONESIAN WOMEN COALITION (KPI) IN EFFORTS TO IMPROVE WOMEN LEADERSHIP IN BLITAR CITY
}

\author{
Dewi Frenti \\ Balitar Islamic University \\ Email: dewifrenti13@gmail.com \\ Anam Miftakhul Huda, \\ Balitar Islamic University \\ Email: A6.asix6@yahoo.co.id
}

\begin{abstract}
Women who have been used as the object of national development is considered to be anfair, due to the current conditions of women already have to be the perpetrators of the change. Their motion is limited in the domestic territory. Indeed, the normative idea contained in the 1945 Constitution has never been a record stating that there is no differentiate between men and women. Politic and election are clear to accommodate women to participate more broadly. The research objectives is to know: 1) kinds of programs of KPI Blitar 2) Supporting factors and inhibitors program of KPI Blitar. This research uses a qualitative approach that describes all the activities of KPI Blitar related to efforts of women empowerment in Blitar. The results of this research indicates: 1) The role of KPI Blitar city in Improving Leadership of female autonomy. 2) Supporting factors of KPI Blitar city which cooperate with government institution, independently, local and national. Internal and external constraint factors lead many women to become activists of rights struggle, and tend to rely on men ability.
\end{abstract}

Key words: Indonesian Women Coalition (KPI), Patriakhi, Domestik.

Received: 12 August, 2017; Accepter: 10 September, 2017

\section{INTRODUCTION}

Indonesia which has status as a developing country always continuously make efforts of development which directed for prosperity of society. In the development process, women have an indispensable role with the process, especially in terms of acculturation with the social environment and the small community. Women should have the same potential as men to contribute the community development. Either in the economic, socio-cultural and political fields of government in the sphere of democracy. 
JARES, Vol. 2 No. 2 September, 2017; p-ISSN: 2502-826X; e-ISSN: 2503-1163

Copyrights@ Balitar Islamic University, Blitar, Indonesia; Http://jares.unisbablitar.ejournal.web.id

Citation: Frenti, Dewi, et. al . 2017. The Function of Indonesian Women Coalition (Kpi) in Efforts to Improve Women Leadership in Blitar City. JARES, (2017), 2(2):19-29

The dominance in public sphere of politics is always synonymous with the role of men. They formulate the rules of the game and they also define the standard of evaluation in the field of the political area (Soekanto, 1999: 69). The dominance of men in the world of politics as well as in institutions has made women's jealousy and opposition to uneven models and lifestyles. Today more than 95 percent of countries that uphold democracy lead to women's empowerment. Namely: rigth to vote and rigth to stand for elections. In this theory, the right to joint for election, to become a candidate and to vote, is based on voting rights, rigth to vote. However, in reality women's suffrage is restricted because basically only men's candidates have the right to vote (Fakih, 1996 : 59). This is not only the case in developing countries which tend to use modern democracy but also in countries that use established democracies. It seems that such phenomena has become habitual and even lifestyles in some developing and developed countries.

The Government has issued a regulation on gender equality as written in the 1945 Constitution as one concrete action in support of women's empowerment. Article 28 I (2) of the 1945 Constitution states that, "Every person shall have the right to be free from discriminatory treatment on any basis and entitled to protection against discriminatory treatment" and strengthened through ratification or process of the adoption of the Convention on the Elimination of All Forms and Attitudes of Discrimination Against Women by CEDAW (Convention on the Elimination of All Forms of Discrimination Against Women) into Law NO.7 years 1984. And also very necessary for the supervision and special rules to be used as a tool of control of treatment to women.

Philosophically, it means that Indonesia guarantees and protects its citizens from discriminatory acts or descriminating acts without differentiate of social, racial, ethnic, cultural, religious or gender status. The mastery and domination of a certain inhuman and unjust civil society group can also be referred to as discriminatory acts, in the preamble of the 1945 Constitution states, "the meaning of freedom is the right of all nations and hence, the occupation of the world must be revoked because it is incompatible with humanity and justice" (Suharto, 2005: 127).

The number of women in the political seat is still low, being brought in the standards already set by the existing rules, so the position of women in the legislative institutions is very small and cause the role of women is very less, especially in the executive position as the decision and policy makers are still minimal, so the existence of women is still not taken into account, although according to BPS data in 2000 the number of women are greater than men in a ranged 52\%: 48\%. Beside quantity, women must have a dominant role so that the political focus will also lead to the quality of women themselves.

A growing image in society that 'women are not worthy to engage in politics' Women do not deserve to lead because women are irrational and rely more on their emotions (Lazarusli, 2006: 9). The low participation and occurrence of gender imbalances are caused by image and social. In this case, gender plays a role because with the equality and balance of the rights of women and men can change the general view that had been inclined to undermine the women become equal and balanced in the role and duties as citizens.

The above phenomenon brings a heavy duty to women activists in empowering their communities, because should be able to break down the social construction of myths, images, bad labels and prejudices that can weak and harm women's existence (Gender sensitivity). A 
JARES, Vol. 2 No. 2 September, 2017; p-ISSN: 2502-826X; e-ISSN: 2503-1163

Copyrights@ Balitar Islamic University, Blitar, Indonesia; Http://jares.unisbablitar.ejournal.web.id

Citation: Frenti, Dewi, et. al . 2017. The Function of Indonesian Women Coalition (Kpi) in Efforts to Improve Women Leadership in Blitar City. JARES, (2017), 2(2):19-29

comprehensive struggle and sacrifice must be done continuously and sustainably by women and other elements of society (Pramudianto, 1999: 18). In this case every effort is not necessarily only the responsibility of women activists but also the necessity of awareness and responsibility of all elements of society.

Non-governmental organization (LSM) appear because of awareness of the importance of human values and development responsibilities. So, LSM allow the growing awareness of the development process that has the same position as the human rights. On the other hand, the closeness of LSM can also be one of the socio-political forces that enable the promotion of sustainable development process in accordance with and in line with the proportion that should and have the nuances of human values. The existence of LSM is able to create harmony between the ruling party and the implementing party (state apparatus) and the LSM that goes in the same direction with different vision for the common interests. Here the LSM become the controlling element of the community against the developments made by the government.

Implementation of acceleration regulation of women empowerment in political field with $30 \%$ quota strategy as mandated in RI Law number 12, 2003 year article 65 paragraph 1, still encountered some quite complicated obstacles. Lack of human resource quality and experience as a politician is also not only the factor that can be a barrier, but also from external factors such as patriarchal culture which implies the low quantity of women in the political sphere. This is evident in the lack of female politicians who enter the elite political parties in every political level. In addition, it is also necessary to improve the regulation of the RI Law of 2003 no 12 article 65 paragraph 1 which is still widely criticized by parties who have shortcomings such as the absence of sanctions or punishment for political parties that do not obey. The rules and punishment should be have a balanced role, which can later create a regular order. The Indonesian Women's Coalition is also an integral part of other pro-democracy mass movements which contribute to the resistance to the New Order regime. Various factors pushed the movement to undermine the New Order's power, namely the monetary crisis that occurred since 1997.

Indonesia's worsening economy, as well as rampant corruption Collusion and Nepotism (KKN), poverty continues to rise. The most prominent social diversity has led to protests and social dissent. Repressive measures such as arrests, disappearances and shootings encourage demonstrations driven by students who then received full support from the people including women as a reaction to society's dissatisfaction with the system and pattern of government at that time. Economic improvement and total reform are the main demands of the demonstrators. On $12^{\text {th }}$ May 1998 a massive Demonstration was held in Jakarta. Around 75 women activists from all over Indonesia include from Timor Leste gathered in Jakarta and agreed to establish a pro-women's movement organization in response to the above situation On $18^{\text {th }}$ May 1998. Then from the results of this meeting was born Coalition of Indonesian Women for Justice and Democracy After two days later, finally President Soeharto resigned from his post as president and gave his position to the vice president of BJ Habibie on May 21, 1998. Since then, the New Order regime ended and the start of the Reform Order.

The Indonesian Women's Coalition Organization is a response of women in the momentum of the opposition of the Women's Movement, Students and other Pro-democracy Groups to the 
JARES, Vol. 2 No. 2 September, 2017; p-ISSN: 2502-826X; e-ISSN: 2503-1163

Copyrights@ Balitar Islamic University, Blitar, Indonesia; Http://jares.unisbablitar.ejournal.web.id

Citation: Frenti, Dewi, et. al . 2017. The Function of Indonesian Women Coalition (Kpi) in Efforts to Improve Women Leadership in Blitar City. JARES, (2017), 2(2):19-29

authoritarian regime of the New Order Government, this is clarified on the content of the Indonesian women's coalition budget. Historically, it has become common knowledge that the New Order regime has destroyed and castrated the women's movement by uniforming and discriminatory ideology and discourse of women.

The First National Congress, which was held in Yogyakarta on Thursday, December 17 to 18, 1998, succeeded in strengthening the Indonesian Women's Coalition as a mass organization based on individual membership. The selection of places in Yogyakarta and the choice of dates and months adjacent to the December 22 anniversary, aims to reestablish the milestones of the Indonesian women's movement that began on December 22, 1928, originally referred to as Mother's Day and then transformed into Women's Day of Movement. From 1999 to 2001, the Indonesian Women's Coalition organized the Regional Congress for the establishment of the Coalition of Women at the provincial level, including the Regional Congresses: West Sumatra, North Sumatra, East Java, Jabodetabek, Bengkulu, South Sulawesi and Yogyakarta Special Territory. From the initial step of establishing the Coalition of Women at the Region level, it is expected that the regional officials make a form of branches to improve the progress of the movement.

\section{RESEARCH METHOD}

This research uses a qualitative-descriptive research, because the descriptive research has the nature of interpretation of data relating to the present situation and experience, the present moment and present-day attitude, the correlation of conflicting variables of two or more conditions, the effect on a condition, the difference between facts, and others. The researcher attempts to describe qualitatively the role of Indonesian Women's Coalition (KPI) Blitar in encouraging the realization of public information disclosure in the form of words or discourse through appropriate interpretation and systematis.Informan research is Mershinta AR Isthaufa Indriani, Nur Hanik, Farida Masrurin ie some board in the KPI Blitar. in this study The data used is in the form of narrative and descriptive data. That is the form of text, written words, and actions that describe or present people and events in place of research

\section{THEORITICAL REVIEW}

Based on the research title above "The Function of Indonesian Women's Coalition (KPI) in Efforts to Improve Women's Leadership in Blitar City" so, an explanation of women's concepts and principals of female leadership is needed

1. Women

Women are gentle and loving creatures because of their subtle feelings. In general, the nature of women are beauty, tenderness, humble and nurturing. That are the characters of women which are often heard around us. In addition, the anatomical and physiological differences also cause differences in behavior, and there are also differences in ability, selective to the intentional activities aimed and directed to the nature of women. Women are also creatures that use emotional greater than rationalnya, it is because women always use their feeling in addressing each problem. 
JARES, Vol. 2 No. 2 September, 2017; p-ISSN: 2502-826X; e-ISSN: 2503-1163

Copyrights@ Balitar Islamic University, Blitar, Indonesia; Http://jares.unisbablitar.ejournal.web.id

Citation: Frenti, Dewi, et. al . 2017. The Function of Indonesian Women Coalition (Kpi) in Efforts to Improve Women Leadership in Blitar City. JARES, (2017), 2(2):19-29

2. The role of women

Women and men have equal role in make effort and work, men and women can work together in various areas of life and there is no comparison between both of them. Nowadays, women's abilities are increasingly visible in various occupations and professions and the quality of their work is not lower than the men. Women's progress and performance is evident through the struggle without gender discrimination. The modern era has greatly changed the society's view of women today. The view that women only have the right to take care for a house has changed with the emancipation that women have the same rights as men. RA.Kartini also firmly calls for the struggle to have modern thoughts and actions for women.

3. Women leadership

In the emphasis of role of gender and the role of leaders, the role of social theory argues that leaders occupy defined roles in their specific positions within the hierarchy and at the same time functioning under the constraints of their roles of gender. In terms of the general definition of social roles as shared social expectations that apply to people who occupy in a certain social positions or members in the social category. The role of gender is a consensual belief about the attributes of women and men who have equal rights in doing anything. The number of women in making decisions will also alter the focus of political life if the number of women has more votes. The impact is the extension of the political area to the problems and issues that are ignored will be the main focus, such as protection of women's reproduction, the welfare of children, and others. Political life may also be more moral because women who occupy the political seat will also be more concerned with conventional political issues such as education, economics, the environment, social welfare rather than hard politics. Women as creatures who use their emotional greater will judge each issue thoroughly, related to the impact and consequences caused by a case or incident.

\section{GENERAL DESCRIPTION OF KPI}

The Indonesian Women's Coalition for Justice and Democracy has the goal of realizing gender equality and justice towards a prosperous and civilized democratic society, founded in May 1998. This women's organization is based on individual membership. Under the mandate of the Third National Congress of the Indonesian Women's Coalition, the Coalition advocacy agenda Indonesian women for the period 2009-2014 is to strive for gender-sensitive public policies; Gender Budget (Gender Responsive Planning and Budgeting); Increasing Women's Representation in Decision Making; Trafficking of Women and Children; Violence Against Women and Children; Women and Fundamentalism; Women and Poverty ; Women and Conflict Areas; Women and Security Reform; Women and the Right to Education; Women and the Right to Work; Women and the Right to Health; Women and the Right to Food and Water; Women and Globalization, Disaster, Environment and Climate Change. At that time advocacy was conducted in 24 provinces, namely Aceh, North Sumatra, Jambi, West Sumatra, DKI Jakarta, West Java, Central Java, East Java, Yogyakarta, South Sulawesi, Central Sulawesi, West Nusa Tenggara, East Nusa Tenggara, 
JARES, Vol. 2 No. 2 September, 2017; p-ISSN: 2502-826X; e-ISSN: 2503-1163

Copyrights@ Balitar Islamic University, Blitar, Indonesia; Http://jares.unisbablitar.ejournal.web.id

Citation: Frenti, Dewi, et. al . 2017. The Function of Indonesian Women Coalition (Kpi) in Efforts to Improve Women Leadership in Blitar City. JARES, (2017), 2(2):19-29

Sulawesi Southeast, North Sulawesi, West Sulawesi, Bali, North Maluku, Banten, Lampung, South Sumatra, East Kalimantan and North Kalimantan.

This organization has budgetary derived from membership fees and contributions from individuals,governmental and non-governmental institutions. And also partnership are some of the international donors supporting the work program of the Indonesian Women's Coalition in the 2009-2014 period, Development and Peace (D \& P Canada), Search for Commond Ground (SCFG), The Asia Foundation (TAF), OXFAM Australia, AusAID, ACCESS, HIVOS and IKAT - US. Meanwhile, the United Nations Agency that cooperates and provides support to the Coalition of Women Indonesia, among others: UNDEF (United Nations Democracy Fund), UN Women, UNODC (United Nations office for Drug and Crime), and UNFPA (United Nations Population Fund).

To improve the Members and Constituent Capacity, the Indonesian Women's Coalition has 10 modules, include: Tiered Education Module (Basic, Secondary and Advanced Education), Leadership Education Module, Voters, Modules for Legislative Candidates (Increased Political Capacity and Campaign Management ), and organizing modules. At the district or city level, the Indonesian Women's Coalition branches work with local governments in arrange of policy formulation, implementation program and budget allocations. The achievements of the Indonesian Women's Coalition for Justice and Democracy can be seen in the gender justice program in the provinces of Nusa Tenggara Barat and Timur, Southeast Sulawesi, Bengkulu, South Sulawesi. Through the gender equality program, the Indonesian Women's Coalition is strengthening the capacity of village women to organize women at the grassroots or the lowest level and approaching the local government to be more responsive to women's needs.

\section{FINDING RESEARCH AND DISCUSSION}

Viewed from the basic principles and tendencies, "the objective of the Indonesian Women's Coalition organization is to support democracy, human rights, equality and gender balance, and diversity with Feminism as its foundation" Farid said as one of the functionaries of KPI Blitar. The principles on gender equality and justice means a situation where women and men enjoy equal status and have equal conditions to fully realize their human rights and potential in all spheres of life. Gender equality means the equal function of women and men in culture and structure. The Indonesian Women's Coalition organization has the achievement to fight for the fulfillment of women's rights in Politics, Economics, Law, Sexuality, Reproduction, Education, Religion, Social and Culture and Environment . Mershinta A.R also said, "KPI Blitar has been implementing programs and activities that are general achievement of KPI Blitar Raya, one of them is by advocating and understanding women about the importance of knowledge and leadership for women". From the panel discussion conducted by the author with some functionaries of KPI BLITAR namely Mersinta A.R, Isthaufa Indriani, Nur Hanik, and Farida Masrurin can be known that KPI always seek the empowerment of women in Blitar, such as mentoring, socialization, etc.

To manifest the situation above, especially to improve women's leadership. KPI Blitar has programs that can be divided into the following classification of activities:

1. Socialization/ counseling 
JARES, Vol. 2 No. 2 September, 2017; p-ISSN: 2502-826X; e-ISSN: 2503-1163

Copyrights@ Balitar Islamic University, Blitar, Indonesia; Http://jares.unisbablitar.ejournal.web.id

Citation: Frenti, Dewi, et. al . 2017. The Function of Indonesian Women Coalition (Kpi) in Efforts to Improve Women Leadership in Blitar City. JARES, (2017), 2(2):19-29

The communication process undertaken by the functionaries / KPI members in order to provide knowledge about empowerment programs as well as women's leadership discussions conducted through the extension process to women, youth, the elderly, and the association of PKK or other women's organizations.

2. Guidance and counseling

With the counseling is a strategic activity in helping the client to be able to steadily make and dare to make their own decisions to follow the program of women's leadership improvement and to help each other in terms of problem solving. This counseling efforts aimed at making women able to rise and not depend on men. so that every woman is able to show attitude and nature of leadership in solving problem.

3. Motivation

The first step in the process of mobilizing the Indonesian Women's Coalition to encourage the establishment of independent and dignified women empowerment is by providing an understanding of leadership, as well as activities of women's movement that leads to leadership motivation for women.

4. Social community

Social community is an effort to prosper the society that is considered to need. At the same time to provide understanding of the importance of having the attitude and the nature of selfreliance and independence. This is deemed necessary to do because to adapt women's leadership skills needed also the welfare of individuals who will lead to the self-confidence and tranquility of women in running their lives.

Based on the above classification, some concrete activities that have been done by KPI are:

1. Discussion hall

Discussion hall is a consolidation effort that is done to find a solution of a problem. Which is also usually implemented by inviting figures / agencies related to the issues concerned. Objectives also train the skills and critical of members built. KPI also always emphasize that the results or achievements of the discussion hall is the rise of women's leadership spirit while moving together and side by side with men.

2. Advocacy on National Health Insurance (JKN) issues

Is a systematic and organized effort that intends to influence and urgent the occurrence of changes in public policy gradually progress. For example, to solve the problems such as BPJS. The purpose of this advocacy is the welfare of the community in the context of health especially women, which then later expected that the women themselves become cadres of the movers with leadership skills that have been obtained from training and mentoring conducted by KPI.

3. Networking

Meeting between functionaries, KPI members and cadres with a broad scope. The aims are to discuss the technical issues that are deemed to be relevant to the problems. Here the 
JARES, Vol. 2 No. 2 September, 2017; p-ISSN: 2502-826X; e-ISSN: 2503-1163

Copyrights@ Balitar Islamic University, Blitar, Indonesia; Http://jares.unisbablitar.ejournal.web.id

Citation: Frenti, Dewi, et. al . 2017. The Function of Indonesian Women Coalition (Kpi) in Efforts to Improve Women Leadership in Blitar City. JARES, (2017), 2(2):19-29

representatives of each region will tell the conflicts and constraints that occur in detail, which then becomes the discussion material and will also determine the strategic steps to resolve the problems and constraints. Or just share the experience between regions. The effort to improve leadership here is to train and familiarize women to dialogue with a wider scope, and to teach women to be able to think critically solusif in solving problems that occurred at the time.

4. Basic Cadre Training (PKD)

Basic Cadre Training is the phase of planting values and the formation of member militancy to become a cadre of KPI. With immediate PKD, formally a person has become a cadre of KPI. PKD is the first phase in the formal of KPI. PKD cadre is conducted in the villages in the scope of Blitar territory that allows them to have the ability and skills to organize. In the PKD is not carried out separately, because according to KPI many women who do not yet understand about the organization and purpose of KPI itself that they want and enter into their organization and services for become a leader.

5. PKL

Advanced Cadre Training is the phase of this cadre to build and strengthen the base of knowledge and skills that will sustain the KPI cadre's current and future mobility options. Advanced Cadre Training is the second phase in the formal of KPI cadre process, held as early as six months after the PKD and not later than two years after the PKD. Graduates of this street vendors are expected to develop leadership in KPI and able to have maturity in knowledge, attitudes and behaviors which the goal is able to develop into subjects who believe in individual capacity. In this PKL phase is a stage of screening or selection stage, the goal is to filter out cadres who indeed already qualified to be members of PKL

\section{GENERAL ACTIVITIES OF KPI}

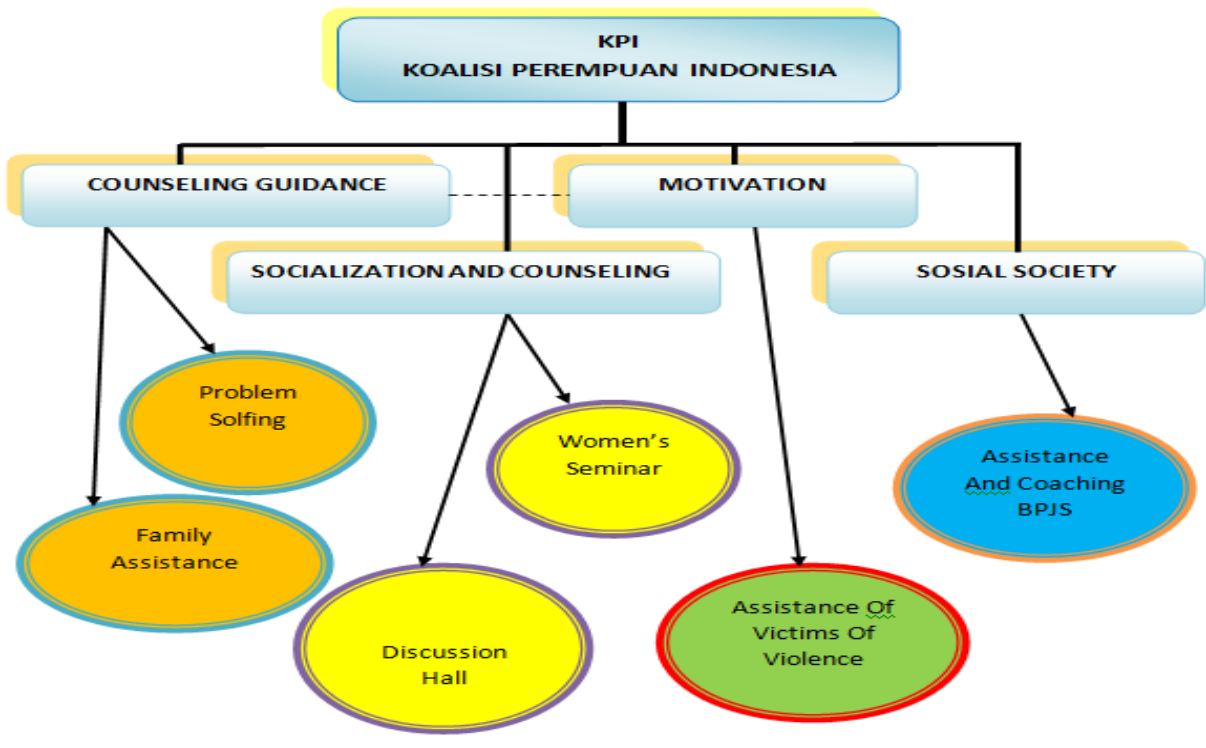


JARES, Vol. 2 No. 2 September, 2017; p-ISSN: 2502-826X; e-ISSN: 2503-1163

Copyrights@ Balitar Islamic University, Blitar, Indonesia; Http://jares.unisbablitar.ejournal.web.id

Citation: Frenti, Dewi, et. al . 2017. The Function of Indonesian Women Coalition (Kpi) in Efforts to Improve Women Leadership in Blitar City. JARES, (2017), 2(2): 19-29

Information:

In general, KPI has classification of activities that serve as a reference and flow of programs or activities support. Some examples of classification is guidance and counseling, socialization and counseling, motivation, and social community. From the classification of the KPI can manifest by implementing support programs such as family assistance, problem solving, discussion hall, women seminars, and mentoring assistance of BPJS.

\section{THE FIELD ACTION OF INDONESIAN WOMEN COALITION IN HANDLING OF}

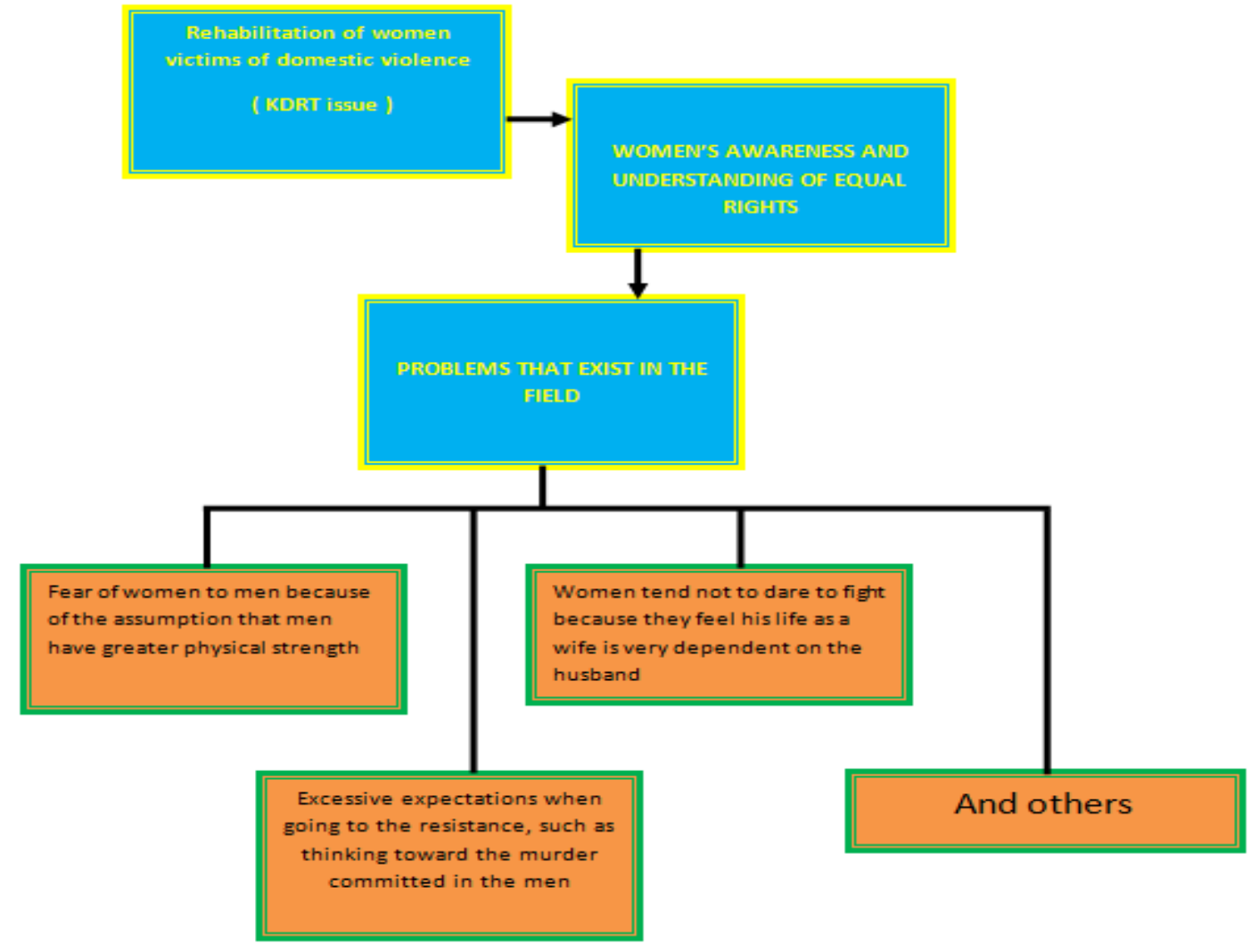

DOMESTIC VIOLENCE (KDRT)

Information :

In its actions in the field, KPI also encountered problems, one of which is related to domestic violence (KDRT). This case has always been the focus of KPI in the effort to train women's leadership because if we are ignore them, the result is being traumatized victims and tend not to have the power to develop self potential. Some of the causes of this case are women's fear of excessive men, the expectation that leads to bad things and a sense of dependence by the victim who thinks his life depends on men. 


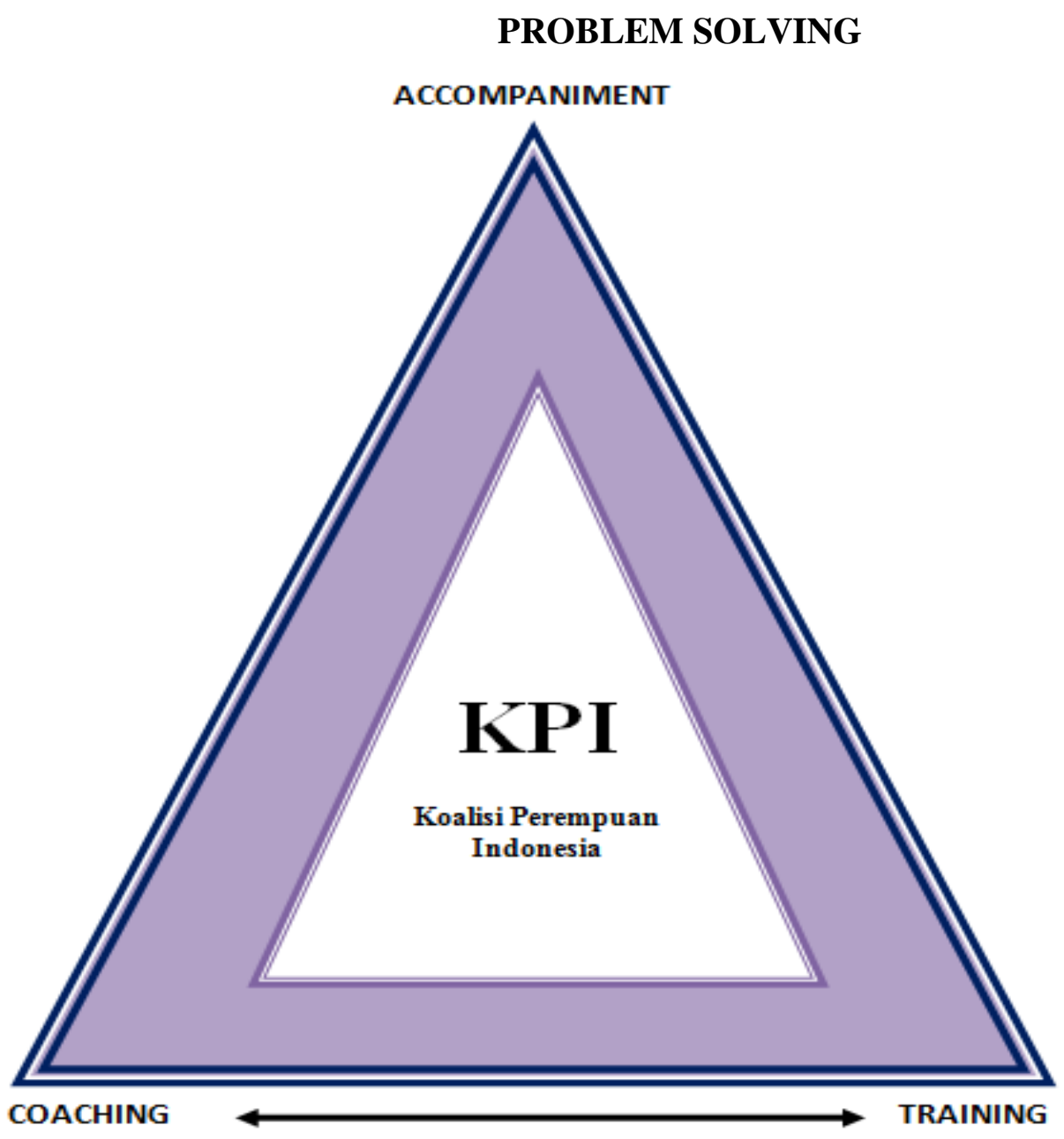

Information :

KPI has a plot and system applied for handling or problem solving. Basically KPI will first train and counsel victims of violence which then also will be accompanied by an exclusive mentoring with the aim that the psychic and trust victims can recover as before the situation gets violent or harassment.

\section{CONCLUSION}

The role of the Indonesian Women's Coalition in Blitar as a whole leads to increased leadership for women. It is based on the fact that there are still many women in Blitar who are not even gender-related, equality of functions and equality in various fields. which is perceived to be able to adapt and support the main achievement of improving women's leadership in Blitar.

Based on the results of interviews conducted by researchers, found the fact that the activities on improving women's leadership in Blitar quite successful. Most of the activities 
JARES, Vol. 2 No. 2 September, 2017; p-ISSN: 2502-826X; e-ISSN: 2503-1163

Copyrights@ Balitar Islamic University, Blitar, Indonesia; Http://jares.unisbablitar.ejournal.web.id

Citation: Frenti, Dewi, et. al . 2017. The Function of Indonesian Women Coalition (Kpi) in Efforts to Improve Women Leadership in Blitar City. JARES, (2017), 2(2):19-29

carried out by KPI Blitar related to the increase of women leadership in politics are quite successful due to the large participation of Blitar women who are interested in politics especially gender equality. It can be said that the participation of women in socialization activities on increasing leadership for Blitar women has been massive. This is reinforced by the results of interviews which states that in every meeting and socialization of women began to be able to dialogue and discussion actively and dare to express an opinion which is then directed as a solution to related problems. On the other hand, in the field of social welfare, has begun the growth of women's spirit to become a cadre mobilizer that is advocating the public in the field of health that is in this case of BPJS.

\section{Refferences}

Budairi, Muhammad, 2002. Civil Society and Democracy. Jakarta: E-law Indonesia. Budiarjo, Miriam, 1992. Basic Political Science. Jakarta : PT Gramedia Widiasarana Indonesia. The Indonesian Women Coalition and Its History, 2012. Buku Saku KPI. Fatah, Eep Saefulloh. Notes on the Political Failure of New Order, Yogyakarta: Pustaka Pelajar. Lexy J, Moelong. 2010. Qualitative Research Methodology. Bandung: PT. Remaja Rosdakarya Offset.

Mosse, Julia Cleves. 1993. Development and Gender. Yogyakarta: Pustaka Pelajar Offset. Utami, Tari. Siwi, 2001. Women Politics in Parliament, Yogyakarta : Gama Media. Patilima, Hamid. 2006. Qualitative Research Methodology. Bandung: ALFABETA. Koderi, Muhammad,1999. Could the Women Lead the Country, jakarta : Gema Insani. Pramudianto. 1999. Islam and Civil Society in Indonesia. Jurnal Madani vol.2 No. 3. Hikam, Muhammad AS, 1996, Democracy and Civil society, PT Pustaka LP3ES, Jakarta. Siti Musdah, Mulia dan Anik farida. 2007. Women and Politic. Jakarta: Gramedia Pustaka Utama. Soekanto, Soerjono, 1991. Sociology: An Introduction. Jakarta: PT. Raja Grafindo Persada. Soetjipto, Widyani, Ani. 2010. Women Politics is not an Eclipse. Jakarta: KOMPAS. 